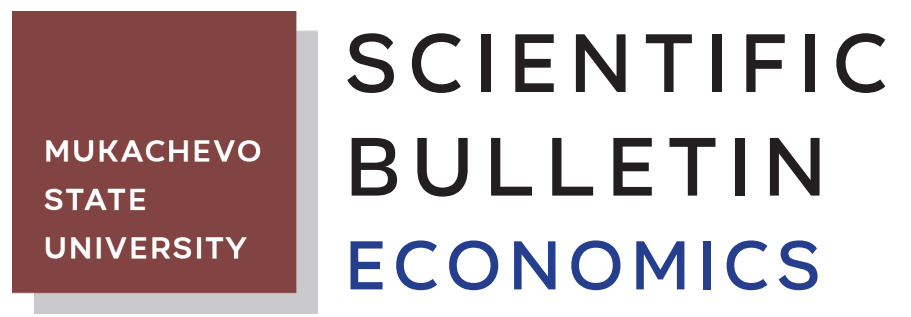

Volume 8, No. 2, 35-44

Journal homepage: https://economics-msu.com.ua/en

UDC 339.9

DOI: 10.52566/msu-econ.8(2).2021.35-44

\title{
The Role of Economic Diplomacy in the System of Modern International Economic Relations
}

\author{
Viktoriia V. Kukharyk ${ }^{1 *}$, Thomas Nübling ${ }^{2}$ \\ ${ }^{1}$ Lesya Ukrainka Volyn National University \\ 43025, 13 Voli Ave., Lutsk, Ukraine \\ ${ }^{2}$ Universität Stuttgart \\ 70174, 7 Keplerstrasse, Stuttgart, Baden-Wurttemberg, Germany
}

\begin{abstract}
The modern globalised world is characterised by economic independence, which is a component that measures the level of relations between countries, the content, direction and intensity of which has begun to be influenced by economic dependence. In other words, economic relations have become central to diplomatic activity, which determines the relevance of the subject matter. The purpose of this study is to determine the role of economic diplomacy in the system of modern international economic relations, to compare the theoretical model of economic diplomacy and the practice of its implementation. This paper uses the following methods: scientific abstraction; monographic, dialectical, historicallogical; structural-logical; abstract-logical; methods of regression analysis; synthesis; problem-oriented method; statistical and graphic methods. The author used a Scatter plot model and performed a regression analysis to determine which free trade area (Ukraine-EU, Ukraine-Canada, or Ukraine-Israel) affects Ukraine's GDP growth. The study model confirms the positive relationship between Ukraine's GDP growth and the growth of foreign trade turnover (FTT) between Ukraine and the EU. The linear model explains that a 1\% increase in FTT affects an average 5\% increase in Ukraine's GDP. At the same time, the regression model shows the opposite trend in terms of FTT between Ukraine and Canada, Ukraine and Israel. Thus, the dynamics of Ukraine's FTT with these countries does not have a significant impact on GDP. Only the growth of FTT between Ukraine and the EU indicates the effectiveness of bilateral cooperation. The practical significance of the results obtained lies in the fact that the theoretical foundations, conclusions, and recommendations obtained and formulated by the author can serve as a basis for further study of issues of economic diplomacy and for the development of such a concept of economic diplomacy, which should take into account the positions of stakeholders to balance the interests of ensuring the national economic security of the state
\end{abstract}

Keywords: economic diplomacy, economic security, national interests, free trade area

Received: 25.02.2021, Revised: 23.03.2021, Accepted: 14.06.2021

Suggested Citation: Kukharyk, V.V., \& Nübling, T. (2021). The role of economic diplomacy in the system of modern international economic relations. Scientific Bulletin of Mukachevo State University. Series “Economics”, 8(2), 35-44. 


\section{Introduction}

The international environment is constantly changing, it is not static, but has a dynamic character, so it offers significant opportunities and creates problems for conducting economic diplomacy. It is during periods of upheaval that new principles are created to regulate relations between countries, which, in turn, can help strengthen the overall international economic system [1]. In addition, there is a growing number of international organisations and forums to meet growing economic needs. Another trend is that contradictions between economic superpowers are growing more and more, and the international economic order requires reforms, so there is an obvious need for a new global order. It is "soft power" and economic diplomacy that can become the key not only to effective policy but also to the rejuvenation of the global economic system [2]. In addition, the role of the economy will continue to strengthen due to the dynamics and trends of international relations, and at the same time difficulties in using economic instruments would increase. With this in mind, states should develop appropriate strategies for implementing economic diplomacy to maintain their relevance in the dynamic international arena.

The next trend is virtual globalisation, which is taking over the world. Virtual (digital) diplomacy began to take shape quite a long time ago, developing along with social networks. This is especially true for political and public diplomacy, while the creation of digital economic diplomacy is beginning only now [3]. Therefore, a strong knowledge base and understanding of the dimensions, opportunities and consequences of economic diplomacy is an invaluable asset for effective inclusive approach strategies leading to successful interaction. Given the above, the practical implementation of economic diplomacy requires innovation, adaptation and a multidisciplinary approach, given that the line between domestic and foreign policy is narrowing, becoming more and more blurred and combined with a large number of participants [4].

To achieve efficiency and success in implementing foreign economic activity, it is necessary to clearly understand what economic diplomacy implies. Therefore, the first step towards achieving appropriate economic diplomacy is to conceptualise it. Taking into account the above, the study of economic diplomacy is relevant among both foreign and Ukrainian researchers.

Issues of economic diplomacy are constantly at the centre of attention of foreign researchers. Thus, Wolcock [5] and Okano-Heijmans [6] suggest that economic diplomacy deals with international economic relations. According to Defbry Margiansyah [7, p. 15], modern economic diplomacy is aimed at "ordinary" commercial diplomacy, but at the same time, it restricts the development of a new economy due to the lack of a concept that supports the functioning of innovation-oriented economic diplomacy. D. Mlinaric, T. Peric, J. Matejas [8, p. 165], suggest that the study and understanding of economic diplomacy require three elements: political influence, economic assets and relations, as well as ways to consolidate the appropriate climate in the political and international environment.
Other researchers, Dubravko Radoshevich and Sanja Radolovich [9] conclude that states that do not have a well-established concept of economic diplomacy cannot play an active role in relations with other countries, but become the object of economic diplomacy of these countries. Carron de la Carriere suggests that diplomacy uses economic weapons to achieve its goals [10]. Kishan Rana believes that economic diplomacy has bilateral, regional, and multilateral dimensions, each of which is important [11].

M. Chaziza [12, p. 26], examining China's economic diplomacy, notes that the concept includes the full range of economic and financial activities, including trade, investment, and all forms of economic cooperation, including public and military diplomacy, along with any other policy that promotes economic gain for China. V. Chohan Usman [1], concludes that all countries should pay at least some attention to economic diplomacy as an international phenomenon, given their institutional assets and capabilities.

In the studies by Ukrainian scientists: V.A. Vergun [13], O.M. Sharov [14], O.E. Likhachev [15], V.D. Shchetinin [16], K.A. Flissak [17], sufficient attention has been paid to the issue of economic diplomacy and its importance in the system of modern international economic relations. However, the development of such a concept of economic diplomacy, which takes into account the position of stakeholders to balance national economic security is a prospect for further research and emphasises the relevance of this study.

The purpose of the study is to determine the role of economic diplomacy in the system of modern international economic relations, compare its theoretical model and practice of implementation, and investigate a wide range of aspects of the implementation of economic diplomacy and the economic interests of countries.

\section{Literature Review}

Despite the rapid development of economic diplomacy and its key role in the system of modern international economic relations, the study of the above-mentioned problems in recent years is relevant both among foreign and Ukrainian scientists who study the issues of protecting national strategic and economic interests of the state, the establishment of favourable conditions for promoting Ukrainian goods and services to foreign markets using the tools of economic diplomacy.

As noted by Wolcock [5], economic diplomacy can be determined by the decision-making process and negotiations in international economic relations, in "key issues such as trade, investment and finance ... there are also topics such as environment and development that have significant economic implications for policy in these areas". According to Carron de la Carriere [10], the economic weapons of diplomacy ensure that the government uses the economic means of pressure at its disposal to achieve its goals (for example, financial assistance or customs privileges, sanctions or open hostility in the form of customs war, the introduction of an embargo or economic blockade, etc.).

Jeremy Garlick [18], studying China's economic 
diplomacy, sees this concept as an attempt to achieve both political and economic goals in a coordinated manner through government initiatives that Chinese commercial entities use for national security purposes.

Ivona Peternel and Martin Gress [19] applied the gravity model of international trade, which presents empirical results of an analysis of Croatian economic diplomacy and its effectiveness in relation to Croatian exports of goods. The results of the study showed a positive correlation between GDP, the distance between countries, and diplomatic personnel in Croatia. The results confirmed the hypothesis that more economic diplomats engaged in diplomatic missions have a positive impact on exports.

Kishan Rana [11] defines economic diplomacy as the process by which countries struggle with the outside world in order to maximise their national benefits in all areas of activity, including trade, investment and other forms of economically profitable exchanges, where they enjoy comparative advantages. Okano-Hejmans [6], studying the features of economic diplomacy at the intersection of international relations, economics and diplomatic studies, concludes that it is a foreign policy practice and strategy based on the premise that economic/commercial interests and political interests reinforce each other, and therefore they need to be considered together.

Economic diplomacy, according to Pierre-Bruno Ruffini [20], is a method or process by which states use the advantages of cross-border economic activity to implement their national interests. The author notes that economic diplomacy also consists in establishing links between corporate players who export or invest abroad and diplomats who represent the state in the international arena and implement geopolitical decisions. Another researcher, U.W. Chohan [1], suggests that economic diplomacy is a multilateral process that uses economic means to achieve diplomatic goals, and vice versa, through the joint creative involvement of international government managers and other important stakeholders. Among Ukrainian authors, the following issues of economic diplomacy are studied:

V.A. Vergun [13] analyses economic diplomacy in the system of factors of Ukraine's international competitiveness. Economic diplomacy, as noted by the researcher, is a multilateral activity that "develops in modern conditions on a bilateral and multilateral basis, and also functions at the mega-, macro-, meso-, micro levels, respectively reflecting the material interests of international economic and monetary-financial organisations, regions, states, branches of the national economy, multinational corporations, economic associations, enterprises".

Of particular note is the position of O.Ye. Likhachev, who under the term "economic diplomacy" implies the joint activities of the state, social, and business circles to implement national economic interests in the world economy, which uses the tools of traditional and modern diplomacy, a set of Ukrainian foreign economic institutions, regional and multilateral structures, its goal is to increase the country's international competitiveness $[15$, p. 3$]$.
K.A. Flissak [17] considers the place of economic diplomacy in the modern international economy and international economic relations; issues of economic security of Ukraine and organisation of activities of economic units of diplomatic missions. The author pays considerable attention to the organisation of diplomatic negotiations, the technology of their conduct and the protocol component.

It is also worth mentioning O.M. Sharov [14, p. 8], who in his study on economic diplomacy concludes that its task "is to achieve economic goals through diplomacy, regardless of whether it uses economic levers to achieve them".

V.D. Shchetinin [16, p. 15] argues that that "economic diplomacy is an alloy of economics and politics, brought to the level of making and implementing managerial decisions, with the help and through which cooperation and rivalry is carried out in the modern world, forms and methods of development and improvement of the market economy are determined, which becomes an important factor in social development and the solution of key problems of economic and social progress".

\section{Materials and Methods}

The information base of the study were materials published in periodicals, scientific papers of Ukrainian and foreign authors, official materials of the State Statistics Committee of Ukraine (in particular, data on foreign economic activity for the period 2017-2020), electronic resources presented on the Internet, analytical calculations performed in the course of the study.

Achieving this goal provided for the use of a set of general scientific and special principles, methods and approaches at the empirical and theoreticallevels of research, in particular: scientific abstraction - to determine the theoretical essence of economic diplomacy; monographic, dialectical, historical-logical - to thoroughly study and consider the theoretical and methodological foundations of the implementation of economic diplomacy; structurallogical - to determine the tasks of economic diplomacy; methods of theoretical generalisation, abstract-logical - to determine the features of the development of economic diplomacy in Ukraine, for theoretical generalisations and conclusions; methods regression analysis - to determine which free trade area - Ukraine-EU, Ukraine-Canada or Ukraine-Israel - affects the GDP of Ukraine; synthesis - to build a regression model; problem-oriented method - to determine the mission of economic diplomacy; statistical and graphical methods - to process and summarise statistical data and their further illustration in tables and graphs for greater clarity.

The study builds a Scatter plot model using Excel, it is a mathematical diagram used to display the values of two variables for a data set.

A regression analysis of the impact of the free trade zone between Ukraine and the EU, Canada, and Israel on Ukraine's GDP was carried out. This method is used to display the state of the relationship between the economic indicators under study. To do this, it is necessary to plot a 
graph in a rectangular coordinate system, and indicate the value of the resulting attribute along the ordinate axis $y$, and along the abscissa axis - the value of the factor attribute $x$. The set of points of effective and factor features is a correlation field. Taking into account the correlation field, it is hypothesised that the relationship between all possible values $x$ and $y$ has a linear character. A linear regression equation has the form $y=b x+a$ [21, p. 68].

To calculate the regression parameters, a calculation table (Table 1) of communications was constructed.

Table 1. Calculation of parameters of regression analysis of the impact of the free trade zone between Ukraine and the EU on Ukraine's GDP

\begin{tabular}{ccccc}
$\boldsymbol{x}$ & $\boldsymbol{y}$ & $\boldsymbol{x}^{2}$ & $\boldsymbol{y}^{2}$ & $\boldsymbol{x} \times \boldsymbol{y}$ \\
38.3 & 112.1 & $1,466.89$ & $12,566.41$ & $4,293.43$ \\
\hline 43.4 & 130.9 & $1,883.56$ & $17,134.81$ & 5681.06 \\
\hline 45.8 & 153.9 & $2,097.64$ & $23,685.21$ & $7,048.62$ \\
\hline 42.1 & 151.5 & $1,772.41$ & $22,952.25$ & $6,378.15$ \\
\hline 169.6 & 548.4 & $7,220.5$ & $76,338.68$ & $23,401.26$ \\
\hline
\end{tabular}
form (1-2):

For the given data, the system of equations has the

$$
4 a+169.6 b=548.4
$$$$
169.6 a+7220.5 b=23401.26
$$

By multiplying equation (1) of the system by (-42.4), a system that can be solved by algebraic addition is obtained. $-169.6 a-7191.04 b=-23252.16$

$169.6 a+7220.5 b=23401.26$

Obtain:

$29.46 b=149.1$

From where $b=5.0611$

Next, it is necessary to find the coefficient " $a$ ” from equation (1):

$4 a+169.6 b=548.4$

$4 a+169.6 * 5.0611=548.4$

$a=-77.4906$

Thus, empirical regression coefficients: $b=5.0611$, $a=-77.4906$ are obtained. Regression equation (3):

$$
y=5.0611 x-77.4906
$$

The regression coefficient $b=5.0611$ demonstrates how the performance indicator changes $y$, if the value of the factor $x$ increases or decreases by one. In the above example with the magnification of $x$ per 1 unit $y$ increases by an average of 5.061 .

Coefficient $a=-77.4906$ demonstrates the predicted level $y$, but only if $x=0$ is located next to the sample values. If $x=0$ is far from the sample values $x$, then a literal interpretation may lead to unreliable results.

By substituting the corresponding values into the regression equation $\mathrm{x}$, the provided values of the effective indicator $y(x)$ for each observation are determined. The relationship between $y$ and $x$ defines the sign of the regression coefficient b (if $b>0$ - direct connection, $b<0$ - inverse relationship), [22, p. 121]. In this example, the connection is direct.

Multiple determination coefficient $R^{2}$ indicates how much the obtained observations confirm the model. $R^{2}=0.6545$, that is, in $65.45 \%$ of cases of changes in $x$ lead to a change $y$. In other words $-R^{2}$ indicates a close relationship between the indicators.

By analogy, a regression analysis of the impact of the free trade zone between Ukraine and Canada, Ukraine and Israel on Ukraine's GDP is carried out.

\section{Results and Discussion}

\section{Economic diplomacy: Theoretical foundations}

Today, economic diplomacy occupies a proper place in the system of international economic relations, since it performs specific functions that are unique to it. That is why economic diplomacy is studied and analysed by both foreign and Ukrainian researchers. Based on the generally accepted definitions of diplomacy, it can be stated that the concept of "economic diplomacy" is understood as the science of international economic relations and a means of implementing the foreign economic policy of the state, where economic non-military practical measures, techniques, methods and tools are combined and prevail over political ones. Thus, according to A.M. Sharov, "the criteria for economic diplomacy belong to the sphere of international economic relations, the sphere of foreign economic policy of the state; the use of negotiations as the main tool for arranging Interstate economic relations by peaceful means; the presence of the institution of civil servantsdiplomats who directly negotiate and perform all other functions provided for by the charter of the diplomatic service of each state" [23, p. 66].

Therefore, the concept of "economic diplomacy" is often used by researchers in a broad and narrow sense. A broader meaning covers not only the international exchange of goods and services, but also other components of international economic relations, such as the international movement of capital and labour, as well as activities leading to the coordination or adoption of economic policies.

This study suggests that economic diplomacy, in a narrow sense, is a part of public service, a public body established abroad, based on written sources of international law in the form of foreign service, regulated by a national body, usually the Ministry of Foreign Affairs or the ministry responsible for foreign economic relations.

This study determines the essence of economic diplomacy by considering its functions. Thus, according to K.A. Flissak [17], the functions of economic diplomacy as specific activity of the state and relevant institutions are: protecting national interests; improving the competitiveness of the national economy; ensuring equal and non-discriminatory conditions for integration into the 
world economy; stimulating exports and export expansion to foreign markets; stimulating effective investment partnership; resolving trade contradictions and trade disputes. The functions of economic diplomacy as a means or tool for implementing the tasks set and achieving strategic goals are: representative; informational; analytical; organisational; presentation; negotiation or communication; stimulating; preventive. The author refers to the functions of economic diplomacy as a separate branch of science in international relations and international cooperation as cognitive, methodological, normative, and predictive [17, p. 69-70].

Based on the analysis of Ukrainian and foreign publications on the subject, the study systematises the main tasks of economic diplomacy, in particular:

1) providing the state leadership with timely and reliable information on the economic situation abroad, foreign economic policy of foreign states, and the activities of international organisations;

2) protection of national strategic and economic interests of the state abroad;

3) improving the country's competitiveness in the world;

4) creating favourable conditions for successful integration of the country into the global economy;

5) creating favourable conditions for access and promotion of Ukrainian goods and services to foreign markets;

6) promotion of socio-economic development of the country;

7) ensuring national and economic security, etc. $[14$, p. 10 ; 17 , p. $60-61 ; 24$, p. 66-67].

The goal of economic diplomacy of any country is to create an "added" economic value, and this is ultimately the achievement of economic growth and well-being of the country [25, p. 669].

\section{Free trade agreement as one of the instruments of economic diplomacy}

The effective use of such a tool as economic diplomacy in the implementation of Ukraine's foreign policy is crucial, as for other countries of the world that are under the influence of modern world processes, such as economic globalisation [26, p. 34]. It is proposed to consider one of the results of economic diplomacy - cooperation on the basis of free trade area agreements (FTA), which is a common form of trade and economic relations between countries and regional associations. It is believed that FTA agreements have an impact on improving the well-being of countries participating in international cooperation. Free trade is also beneficial because there is an exchange of goods, technologies, access to a variety of products, and so on. Given this, many countries conclude FTA agreements [27, p. 89].

Currently, there are 16 signed free trade agreements in Ukraine, which apply to 45 countries. It is with the EU that Ukraine has concluded the broadest FTA. Other agreements are narrower. For example, Ukraine has signed a free trade agreement with Canada, which covers trade in goods and public procurement; agreements with Georgia and Macedonia relate to trade in goods; agreements with Montenegro - trade in goods and services. In addition, Ukraine has an FTA with the countries of the European Free Trade Association (Iceland, Liechtenstein, Norway, Switzerland) [28].

The association agreement between Ukraine and the EU is a new stage in the development of economic relations, which is aimed at creating a deep and comprehensive free trade area (DCFTA) and gradually integrating Ukraine into the EU internal market. After a lengthy ratification process, the EU-Ukraine Association Agreement entered into full force on September 1, 2017. The agreement provides for "the introduction of conditions for enhanced economic and trade relations that would lead to the gradual integration of Ukraine into the EU internal market, in particular through the creation of a deep and comprehensive free trade area, as defined in Section IV ("trade and trade-related issues") of this agreement, and to support Ukraine's efforts to complete the transition to a functioning market economy, in particular by gradually adapting its legislation to acquis EU (acquis EU is the property of European integration in the political, legal and economic spheres, which is based on European common values, that is, it is a set of rights and obligations of EU member states)" [29].

It is proposed to analyse the dynamics of Ukraine's foreign trade with the EU (Fig. 1).

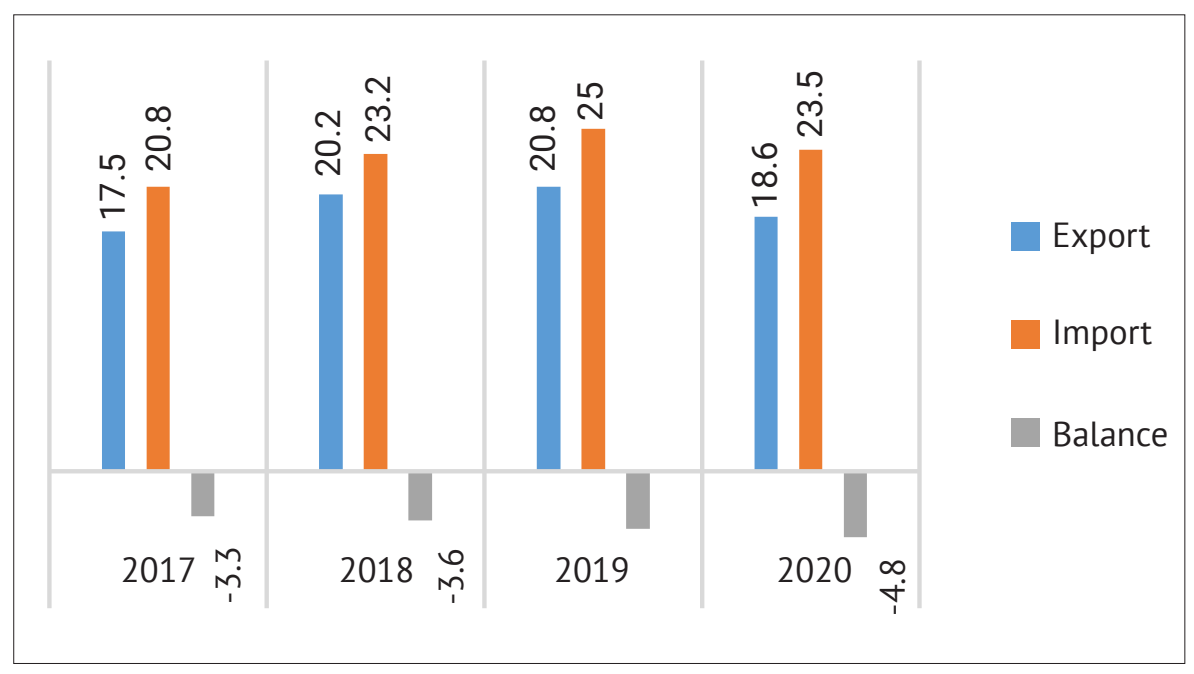

Figure 1. Foreign trade of Ukraine in goods with EU countries in 2017-2020, billion USD Source: compiled by the author based on [30-33] 
According to the Bulletin of the current state of trade relations between Ukraine and the European Union in 2019-2020, Ukraine has the closest trade ties with the EU. It is the EU that accounts for $40.7 \%$ of trade in goods and services from the total volume of trade in Ukraine in 2020 [30].

Figure 1 indicates that there is no stable dynamics in terms of the growth rate of export-import operations of Ukraine with the EU countries during 2017-2020 (the figure shows both the growth and reduction of indicators). Thus, according to the results of 2020, according to the State Statistics Service of Ukraine [34], the volume of exports of goods to the EU and imports of goods from the EU decreased by $10.6 \%$ and $6 \%$, respectively. The trade balance with the EU in 2017-2020 remains negative for Ukraine, but increased to USD -4.8 billion (in 2019 the balance was USD -4.2 billion), which is largely due to non-compliance of Ukrainian goods with European standards, as well as lower quality of Ukrainian products and limited access to markets for certain goods.

The reduction in Ukraine's foreign trade with the EU countries in 2020 is the result of the fact that the total volume of foreign trade in goods of Ukraine decreased by $6.4 \%$ compared to 2019 , which is associated with the crisis caused by the COVID-19 pandemic. The above-mentioned reduction occurred because imports of goods decreased by $10.3 \%$, while exports of goods decreased by $1.7 \%$. The WTO predicted that there will be a $9.2 \%$ reduction in global trade in goods in 2020. Consequently, the decrease in the total volume of foreign trade in Ukraine, in comparison with the forecasts of the service station, is at a better level [35].

This study agrees with [36], and suggests that the positive and negative factors hindering the growth of production and sales of Ukrainian export-oriented products in the EU markets are:

1. As part of increased competition and market liberalisation under the rules of the free trade zone "plus", the Ukrainian manufacturer is forced to look for alternative options for earning and obtaining additional profit, give preference to tolling production schemes, providing services for technological support of finished products, as well as a reorientation to a partial production cycle;

2. A significant obstacle to the activation of export operations is raw material dependence on foreign imports, which significantly increases the cost item in production and indicates that for the production of better products, it is necessary to have better material and raw material potential, which is not easy to get due to inflated supplier prices and transportation costs;

3. An important factor in the manufacturing of products for export is that together with the instability of the exchange rate, it is not easy to conclude a profitable foreign trade contract, since the fixed price will change within the dynamics of exchange differences and currency interventions in foreign markets, which will lead to an increase in the final cost of production;

4. The process of reforming the Ukrainian system of technical regulation and institutional transformations within the framework of the transition of production to
EU international standards require an increase in financial resources for compliance and implementation of the quality parameters of export production in accordance with these requirements;

5. Reorientation of Ukrainian exports in favour of transit services for importing resources, materials and raw materials is necessary [36, p. 112].

However, the potential advantages of DCFTA for Ukrainian producers are: duty-free access to one of the most powerful and largest markets in the world for most Ukrainian products (from the first year of the agreement, the EU abolished import duties on most goods (99\% of tariff lines); equal conditions of competition and increasing export volumes to the EU; improving the quality and safety standards of Ukrainian products, including in the national market; creating Ukrainian brands that would be easily recognised around the world; expanding the range of goods and services in the national market of Ukraine; increasing demand for Ukrainian products, including in the markets of third countries, in connection with the introduction of the improved structure of Ukrainian exports in the direction of reducing the raw material component and increasing the share of high-tech goods with a high share of added value produced in Ukraine [37].

One of the main economic events in 2017 was the signing of an agreement on the creation of a free trade zone between Ukraine and Canada [38]. This agreement is the first signed with a North American country and breaks off duty-free access to a new market for Ukraine, diversifies trade flows, and creates advantages for Ukrainian businesses. According to the agreement, it is planned to deepen trade and economic cooperation between the two countries on trade in goods, protection of intellectual property rights, public procurement, etc. It is planned that the agreement should open $98 \%$ of the Canadian goods market to Ukrainian exporters, while Ukraine is obliged to cancel tariffs for about $80 \%$ of imported goods from Canada [39].

The dynamics of bilateral trade between Canada and Ukraine in 2017-2020 is shown in Figure 2. An analysis of the dynamics of bilateral cooperation between Ukraine and Canada shows that over the past year there has been a decrease in imports and an increase in exports of goods from Canada (Fig. 2), which forms a negative balance of foreign trade for Ukraine. Thus, according to the results of 2020, according to the State Statistics Service of Ukraine [34], the volume of exports of goods to Canada decreased by $5.8 \%$, while the volume of imports of goods from Canada increased by $3 \%$. The trade balance with Canada in 2017-2020 remains negative for Ukraine, but increased to USD - 12 billion (in 2019 the balance was USD -10.9 billion).

On January 1, 2021, the agreement on free trade in goods, signed by Ukraine and Israel in January 2019, has entered into force [40]. The agreement with Israel is a classic one, since it mainly concerns agreements on the reduction or abolition of import duties, which distinguishes it from the DCFTA with the EU, which concerns not only trade in goods and services, but also the protection of intellectual property rights [41]. 


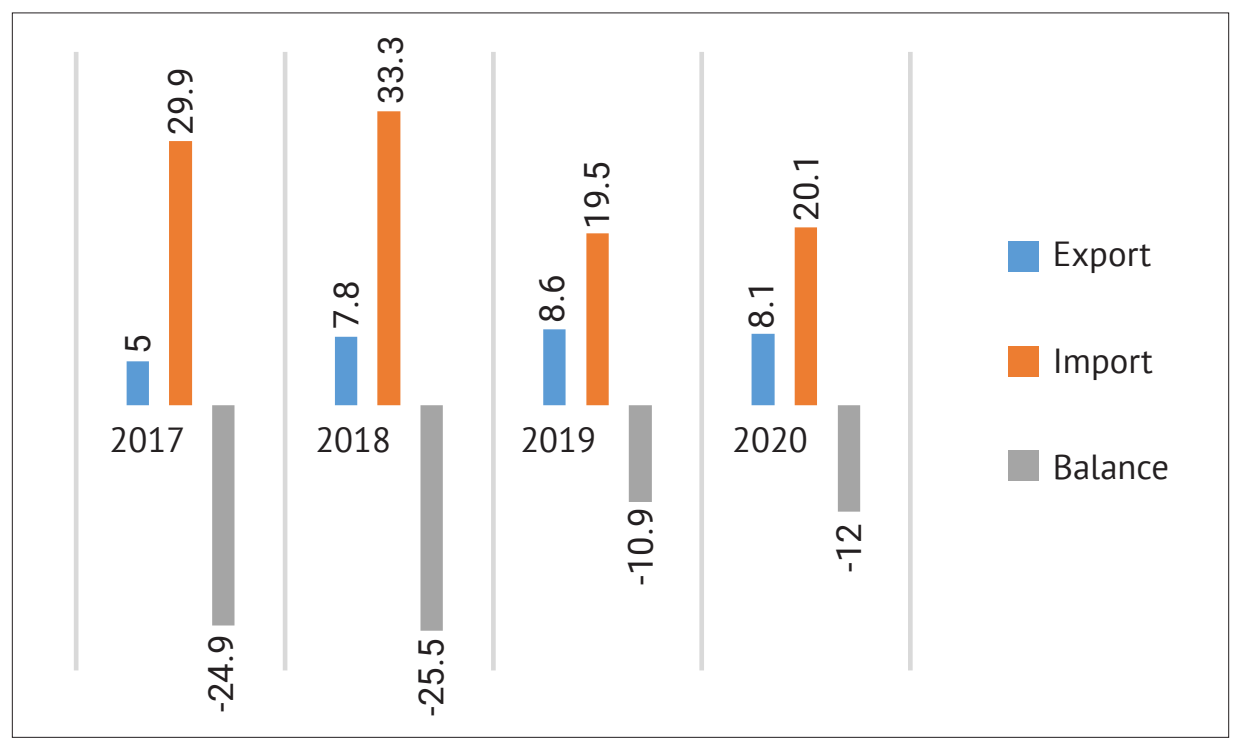

Figure 2. Foreign trade of Ukraine in goods with Canada in 2017-2020, billion USD Source: compiled by the author based on $[34 ; 37]$

Figure 3 shows the dynamics of bilateral trade between Israel and Ukraine in 2017-2020. An analysis of the dynamics of bilateral cooperation shows that over the past year there has been a decrease in imports and exports of goods from Israel (Fig. 3), which forms a positive balance of foreign trade for Ukraine. Thus, according to the results of 2020, according to the state statistics service of Ukraine [34], the volume of exports of goods to Israel and imports of goods from Canada decreased by $9.7 \%$ and $19 \%$, respectively. The trade balance with Israel in 2017-2020 remains positive for Ukraine, but decreased to USD 3.9 billion (in 2019 the balance was USD 4.2 billion).

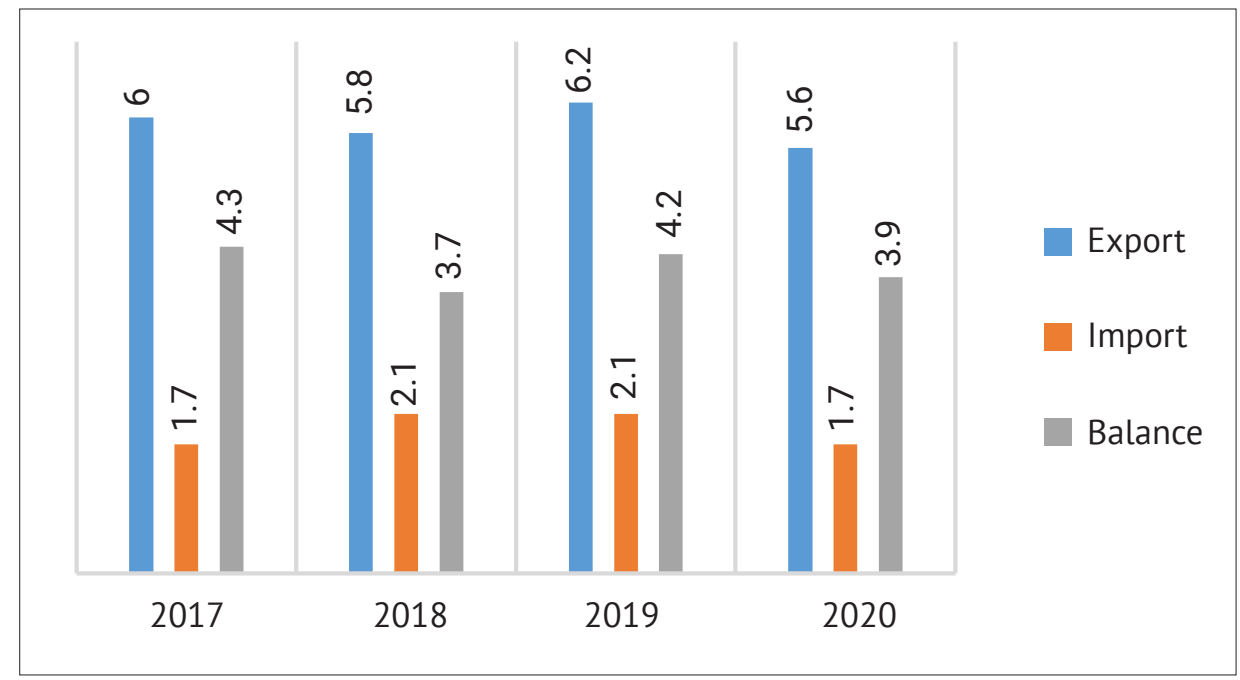

Figure 3. Foreign trade of Ukraine in goods with Canada in 2017-2020, billion USD Source: compiled by the author based on [34]

As part of the free trade agreement, Israel will abolish approximately $80 \%$ of all duties against Ukrainian industrial goods and $9 \%$ of duties that are applied against agricultural goods. In return, Ukraine will also cancel approximately $70 \%$ of duties applied to Israeli industrial products and $6 \%$ of duties against agricultural products [41].

\section{Scatter plot model of the impact of foreign trade turnover between Ukraine and the EU, Canada, and Israel on Ukraine's GDP}

It is proposed to study the effectiveness of bilateral relations using the Scatter plot model. This model would allow studying the impact of foreign trade turnover (for goods) between Ukraine, the EU, Canada, and Israel on Ukraine's GDP (Fig. 4.). For analysis, annual data from 2017 to 2020 from the State Statistics Service of Ukraine was used [34]. Therefore, only the coefficient of determination of the FTT model between Ukraine and the EU confirms its adequacy, since $R^{2}=0.65$. Therefore, in the situation under study, $65 \%$ of the total GDP variability is explained by changes in the FTT. It can be argued that the growth of the FTT between Ukraine and the EU significantly improves the country's GDP. 


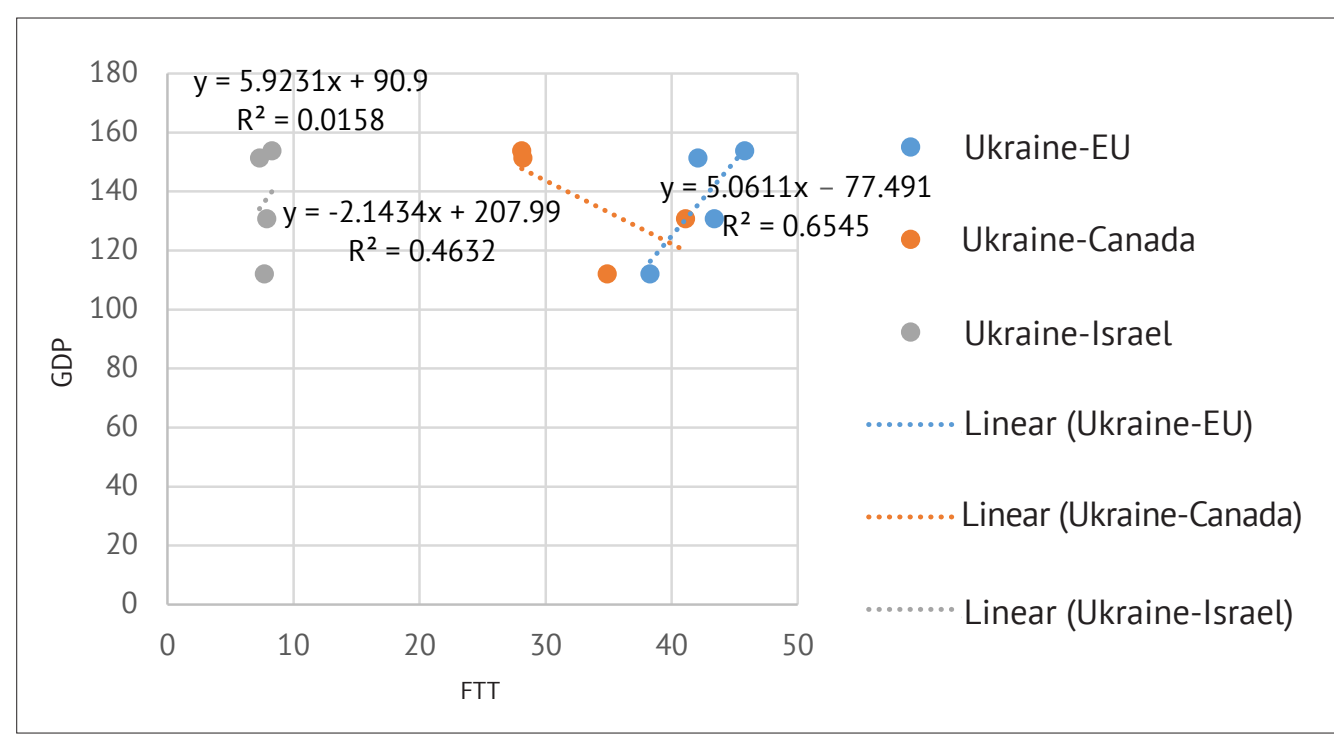

Figure 4. Impact of the FTT between Ukraine and the EU, Canada and Israel on Ukraine's GDP Source: compiled by the author based on [34]

The regression coefficient $b=5.061$ demonstrates the average change in the performance indicator (in units of measurement in) with an increase or decrease in the value of factor $\mathrm{x}$ per unit of measurement. In this case, with an increase in $x$ per 1 unit $y$ increases by an average of 5.061. Consequently, the increase in Ukraine's FTT by $1 \%$ is accompanied by a 5\% increase in the country's GDP, which indicates the effectiveness of bilateral cooperation, primarily for the Ukrainian economy. The relationship between $y$ and $\mathrm{x}$ defines the sign of the regression coefficient $\mathrm{b}$ (if $b>0$ the connection is direct if $b<0-$ inverse relationship). In this example, the relationship is direct.

At the same time, as of today, the growth of FTT between Ukraine and Canada, Israel does not have a significant impact on Ukraine's GDP.

Summing up, it should be noted that Ukraine is trying to use as effectively as possible such a tool of economic diplomacy as the signing of free trade agreements, which contributes to the liberalisation of bilateral trade and the development of profitable relations with partners. The signing of 16 free trade agreements and the current negotiations with Turkey on the agreement indicate that Ukraine is moving in a positive direction. Integration of countries into the global network of trade flows helps to increase its competitiveness, create a favourable investment climate, increase export opportunities, and so on.

\section{Conclusions}

Thus, the main mission of economic diplomacy is to create and provide promising conditions for access and promotion of Ukrainian goods and services to the international arena, protect the national strategic and economic interests of the country in the world, as well as through the use of tools of economic diplomacy to improve the country's competitiveness in the region and the world, ensure national and economic security, etc.

Economic diplomacy forms an effective mechanism for managing global processes, both in the interests of individual countries and the international community as a whole. It is economic diplomacy, using a variety of tools, which allows balancing the results of world economic development for national economies, groups of states and entire regions, preventing the escalation of trade and economic conflicts, etc.

At the same time, economic diplomacy, which is based on significant financial, organisational, informational and other resources of the state, can become, in case of ill-considered use of it, a destructive factor for the world economy, which can disrupt its integrity and the existing stable interdependencies. Therefore, the most important task of modern economic diplomacy is to effectively integrate national interests into the overall context of ensuring the sustainable development of the regional and global economy.

\section{References}

[1] Chohan, U.W. (2021). Economic Diplomacy: A Review. CASS Working Papers on Economics \& National Affairs, Working Paper ID: EC007UC. doi: 10.2139/ssrn.3762042.

[2] Yueh, L. (2020). Economic Diplomacy in the 21 st Century: Principles and Challenges. Retrieved from https://www.lse.ac.uk/ideas/publications/updates/economic-diplomacy-in-the-21st-century-principles-and-challenges.

[3] The rise of digital economic diplomacy. Retrieved from https://www.netherlandsandyou.nl/latest-news/news/2020/07/15/ the-rise-of-digital-economic-diplomacy.

[4] Okoth, J.A. (2012). Economic diplomacy: Dimensions and implications. Keniya: University of Nairobi-Institute of Diplomacy and International Studies. 
[5] Woolcock, S. (2011). EU Economic Diplomacy: The Factors Shaping Common Action. In P.A.G. van Bergeijk, M. Okano-Heijmans, \& J. Melissen (Eds.), Economic Diplomacy: Economic and Political Perspectives (pp. 83-100). Leiden: Martinus Nijhoff Publishers and VSP.

[6] Okano-Heijmans, M. (2011). Conceptualizing economic diplomacy: The crossroads of international relations, economics, IPE and diplomatic studies. In P.A.G. van Bergeijk, M. Okano-Heijmans, \& J. Melissen (Eds.), Economic Diplomacy: Economic and Political Perspectives (pp. 7-36). Leiden: Martinus Nijhoff Publishers and VSP.

[7] Margiansyah, D. (2020). Revisiting Indonesia's economic diplomacy in the age of disruption: Towards digital economy and innovation diplomacy. Journal of ASEAN Studies, 8(1), 15-39. doi: 10.21512/jas.v8i1.6433.

[8] Mlinarić, D., Perić, T., \& Matejaš, J. (2019). Multi-objective programming methodology for solving economic diplomacy resource allocation problem. Croatian Operational Research Review, 10(1), 165-174. doi: 10.17535/crorr.2019.0015.

[9] Škare, M., Radošević, D., \& Radolović, S. (2020). Measuring the macroeconomic impact of economic diplomacy using varfima model for Croatia 1990-2018. Economics \& Sociology, 13(3), 230-243. doi: 10.14254/2071-789X.2020/13-3/14.

[10] de la Carrière, G.G. (2003). Economic diplomacy. Diplomat and market. Moscow: MGIMO University. Retrieved from http://lib.bbu.edu.az/files/book/439.pdf.

[11] Rana, K.S. (2007). Economic diplomacy: The experience of developing countries. Retrieved from https://kishanrana. diplomacy.edu/wp-content/uploads/2019/12/DevCountries-EcoDip-Bayne-2007.pdf.

[12] Chaziza, M. (2019). China's economic diplomacy approach in the middle east conflicts. China Report, 55(1), $24-39$. doi: $10.1177 / 0009445518818210$.

[13] Vergun, V.A. (2008). Economic diplomacy in the system of factors of international competitiveness of Ukraine. Current Issues of International Relations, 74(1), 150-154.

[14] Sharov, O.M. (2019). Economic diplomacy: Basics, problems and prospects. Kyiv: NISS.

[15] Likhachev, A.E. (2006). Russia's economic diplomacy. New challenges and opportunities in the context of globalization. Moscow: CJSC "Economics" Publishing House.

[16] Shchetinin, V.D. (2001). Economic diplomacy. Moscow: International Relations.

[17] Flissak, K.A. (2013). Economic diplomacy. Ternopil: "New color".

[18] Garlick, J., \& Havlová, R. (2020). China's "Belt and road” economic diplomacy in the Persian Gulf: Strategic hedging amidst Saudi-Iranian Regional Rivalry. Journal ofCurrent Chinese Affairs, 49(1), 82-105. doi: 10.1177/1868102619898706.

[19] Peternel, I., \& Grešš, M. (2021). Economic diplomacy: Concept for economic prosperity in Croatia. Economic Research-Ekonomska Istraživanja, 34(1), 109-121. doi: 10.1080/1331677X.2020.1774788.

[20] Ruffini, P.-B. (2016). International trade and foreign affairs - some reflections on economic diplomacy. Journal of International Logistics and Trade, 14(1), 3-28. doi: 10.24006/jilt.2016.14.1.3.

[21] Eytutis, G., Kletsk, T., Krishchenko S., \& Zits, A. (2016). Formation of key indicators to assess the effectiveness of business processes infrastructure JSC "Ukrzaliznytsia". Collection of Scientific Research Papers State University of Infrastructure and Technologies. Section "Economics and Management", 37, 64-75.

[22] Abramova, M.V. (2016). The mechanism of estimating the impact of the military-economic component on the state of economic security of the national economy (Candidate dissertation, Higher Educational Institution "National Academy of Management", Kyiv, Ukraine).

[23] Sharov, O.M. (2018). Economic diplomacy as a symbiosis of science and politics. International Economic Policy, 1(28), 63-87.

[24] Lapin, A.A. (2019). Economic diplomacy as a type of diplomatic activity. Humanitarian Sciences Financial University Bulletin, 9(3), 65-72.

[25] Škare, M., \& Radolović, S. (2020). A long memory model for economic diplomacy in Croatia. Journal of Security and Sustainability Issues, 10(2), 669-682. doi: 10.9770/jssi.2020.10.2(24).

[26] Khmel, A., \& Tykhonenko, I. (2020). Latin American direction of Ukrainian economic diplomacy: The overview of successes and failings. Academic Journal of Interdisciplinary Studies, 9(1), 34-55. doi: 10.36941/ajis-2020-0004.

[27] Tobing, F.B.L., \& Virgianita, A. (2020). Functional multi-track and multilevel economic diplomacy to strengthen trade relations between Indonesia, Chile, and Peru. Regions and Cohesion, 10(1), 88-107. doi: 10.3167/reco.2020.100106.

[28] Information on the conclusion of free trade agreements with individual countries and groups. (2014). Retrieved from https://www.me.gov.ua/Documents/Detail?lang=uk-UA\&id=9538dee1-a00d-4b82-8a8d-ccfaee253185\&title=Ugodi ProVilnuTorgivliu.

[29] Association Agreement between Ukraine, of the one part, and the European Union, the European Atomic Energy Community and their Member States, of the other part. (2014). Retrieved from https:/www.kmu.gov.ua/diyalnist/ yevropejska-integraciya/ugoda-pro-asociacyu.

[30] Bulletin of the current state of trade relations between Ukraine and the European Union. (2021). Retrieved from https://www.me.gov.ua/Documents/Detail?lang=uk-UA\&isSpecial=True\&id=6b2412a2-219c-4aa9-b4ef-87f9690e52 0f\&title=BiuletenPotochnogoStanuTorgovelnikhVas20inouizinuNidnosinoMiz.

[31] Fryzorenko, A. (Ed.). (2018). Cooperation between Ukraine and EU countries in 2017. Kyiv: State Statistics Service of Ukraine. 
[32] Fryzorenko, A. (Ed.). (2019). Cooperation between Ukraine and EU countries in 2018. Kyiv: State Statistics Service of Ukraine.

[33] Fryzorenko, A. (Ed.). (2020). Cooperation between Ukraine and EU countries in 2019. Kyiv: State Statistics Service of Ukraine.

[34] Official website of the State Statistics Service of Ukraine. (n.d.). Retrieved from http://www.ukrstat.gov.ua/.

[35] Us, I.V. (2020). Regarding foreign trade in goods of Ukraine in 2020. National Institute for Strategic Studies. Retrieved from https://niss.gov.ua/sites/default/files/2021-01/zed-2020.pdf.

[36] Savitsky, A.V. (2019). Ukraine's foreign trade in goods with EU countries in conditions of macroeconomic instability. Scientific Bulletin of Uzhhorod National University. Series: International Economic Relations and the World Economy, 25(2), 111-115.

[37] Trade with the EU in 2019 in facts and figures. (2020). Retrieved from https://eu-ua.kmu.gov.ua/zona-vilnoi-torhivli.

[38] Agreement No. 1917-VIII “On Free Trade between Ukraine and Canada". (2017, March). Retrieved from https://zakon.rada.gov.ua/laws/show/124_052-16\#Text.

[39] Brochure "Free trade agreement between Ukraine and Canada: New horizons for Ukrainian business". (2015). Retrieved from https:/www.me.gov.ua/Documents/Detail?lang=uk-UA\&id=805781ab-b0fb-4559-a9ee-9daa7e44fc b0\&title=BroshuraugodaProVilnuTorgivliuMizhUkrainoiu-aPnesKanadoi.

[40] Free trade agreement between the Cabinet of Ministers of Ukraine and the Government of the State of Israel. (2019). Retrieved from https://www.me.gov.ua/Documents/List?lang=uk-UA\&id=deda16bd-13bf-4d66-8a6c-ab30839dc8e $\mathrm{d} \&$ tag=UgodaProVilnuTorgivliuMizhKabinetomMinistrivUkrainiTaUriadomDerer.

[41] Movchan, V. (2019). Free trade and nothing extra: What gives Ukraine an FTA with Israel. Retrieved from https://www.eurointegration.com.ua/articles/2019/01/24/7091965/.

\title{
Роль економічної дипломатії в системі сучасних міжнародних економічних відносин Вікторія Василівна Кухарик', Томас Нюблінг ${ }^{2}$ \\ ${ }^{1}$ Волинський національний університет імені Лесі Українки 43025, просп. Волі, 13, м. Луцьк, Україна \\ Штутгартський університет 70174, Кеплерштрассе, 7, м. Штутгарт, Баден-Вюртемберг, Німеччина
}

\begin{abstract}
Анотація. Сучасний глобалізований світ характеризується економічною незалежністю, яка є складовою, що вимірює рівень відносин між країнами, на зміст, напрям та інтенсивність яких почала впливати економічна залежність. Тобто економічні відносини стали центральними в дипломатичній діяльності, що визначає актуальність обраної тематики. Метою даної статті є визначити роль економічної дипломатії в системі сучасних міжнародних економічних відносин, порівняти теоретичну модель економічної дипломатії та практику іiі реалізації. У статті використані такі методи: наукової абстракції; монографічний, діалектичний, історико-логічний; структурно-логічний; абстрактно-логічний; методів регресійного аналізу; метод синтезу; проблемно-орієнтований метод; статистичний і графічний методи. Автором використано Scatter plot модель та здійснено регресійний аналіз для визначення яка зона вільної торгівлі (Україна-ЄС, Україна-Канада, чи Україна-Ізраїль) впливає на ріст ВВП України. Модель дослідження підтверджує позитивний зв’язок між зростанням ВВП України та зростанням зовнішньоторговельного обороту (ЗТО) між Україною та ЄС. Лінійна модель пояснює, що збільшення 3ТО на 1 \% впливає на збільшення ВВП України в середньому на 5 \%. Водночас, регресійна модель демонструє протилежну тенденцію щодо ЗТО між Україною та Канадою, Україною та Ізраїлем. Так, динаміка ЗТО України з цими країнами не здійснює значний вплив на ВВП нашої країни. Отже, лише зростання ЗТО між Україною та ЄС свідчить про ефективність двосторонньої співпраці. Практична цінність одержаних результатів полягає в тому, що теоретичні основи, висновки та рекомендації, отримані та сформульовані автором у процесі дослідження, можуть служити базою для подальших досліджень питань економічної дипломатії та для розробки такої концепції економічної дипломатії, яка має враховувати позиції стейкхолдерів для збалансування інтересів щодо забезпечення національної економічної безпеки держави
\end{abstract}

Ключові слова: економічна дипломатія, економічна безпека, національні інтереси, зона вільної торгівлі 